\title{
NUTRITIONAL PROFILE, MINERAL CONTENT AND IN VITRO ANTIOXIDANT POTENCY OF CAPSICUM ANNUM L. CULTIVATED IN 24 PARGANAS [SOUTH], WEST BENGAL, INDIA
}

\author{
MOUMITA DAS ${ }^{a}$, SUBHASHREE BASU ${ }^{a} b$, ANURUPA SEN ${ }^{a, c}$, GOURIPROSAD DATTA ${ }^{a *}$ \\ aDepartment of Physiology, Rammohan College, 85A, Raja Rammohan Sarani, Kolkata: 700009, West Bengal, India, bepartment of \\ Physiology, Tamralipta Mahavidyalaya, Tamluk, Purba Medinipur, cDepartment of Physiology, City College, Kolkata \\ Email: dattagp@yahoo.co.in
}

Received: 22 Sep 2016 Revised and Accepted: 18 Nov 2016

\section{ABSTRACT}

Objective: Capsicum annum $L$. is a well-known spice and has long been used in Chinese traditional medicine for the treatment of various ailments. So, the present study was aimed to analyse its nutritional profile and free radical scavenging activity.

Methods: The green Capsicum annum L. cultivated in 24 Parganas [South], West Bengal, were studied for the quantitative analysis of proximate composition, mineral and vitamin content. Aqueous and hydroethanolic extracts were screened on a comparative basis for the presence of in vitro antioxidant potential including the total phenol and flavonoid content, along with ferric reducing power, and 2,2-diphenyl-1-picrylhydrazyl (DPPH), hydroxyl and superoxide radical scavenging activity.

Results: The sample was found to contain $89.89 \%$ total carbohydrate, $13.48 \%$ soluble carbohydrate, $7.95 \%$ crude protein, $4.80 \%$ fat, $12.9 \%$ fibre, 95.42\% moisture and $5.12 \%$ ash. Besides, the vegetable was also found to be abundant in vitamins and minerals like, sodium (24.4), iron (4.834), zinc (1.632), magnesium (92.612), manganese (0.88), calcium (19.562), copper (1.11), cobalt (0.02), chromium (0.016), boron (0.316), lycopene (2.4) and $\beta$-carotene (14.85) expressed in $\mathrm{mg} / 100 \mathrm{~g}$; and potassium (2.236), vitamin C (1.77), vitamin $\mathrm{E}$ (6.08), all expressed in $\mathrm{g} / 100 \mathrm{~g}$ dry weight of the sample. The free radical scavenging activity, total phenol and flavonoid content of the aqueous extract were significantly higher than the hydroethanolic extract $(\mathrm{p}<0.05)$

Conclusion: It can thus be concluded that capsicum is a nutritionally rich spice and a potential source for antioxidant. The aqueous extract is more potent than the hydro-ethanolic extract in scavenging free radical.

Keywords: Capsicum annum L., Phytoconstituents, Proximate Composition, Free Radical Scavenging Activity, Antioxidant Potential, Oxidative Stress

(C) 2017 The Authors. Published by Innovare Academic Sciences Pvt Ltd. This is an open access article under the CC BY license (http://creativecommons.org/licenses/by/4. 0/)

DOI: http://dx.doi.org/10.22159/ijpps.2017v9i1.15311

\section{INTRODUCTION}

A variety of strategies are being applied by the developing countries to continue the fight against malnutrition. In many tropical countries, rural people traditionally harvest a wide range of vegetables and fruits because of its taste, cultural uses, as food supplements or to tide over food shortage [1]. In order to meet the ever increasing food demand, cultivable and wild vegetables are often used as cheap food source for the marginal communities. To apprehend the situation, interests have been centralized on the exploration and quantification of nutrient content of commonly consumed vegetables.

The quality of food depends upon the presence of a relative concentration of various nutrients such as protein, fat, carbohydrate, vitamins and minerals. Vegetables are a rich source of carbohydrate, fat and protein, which forms a major portion of the human diet. Besides, the moisture, fibre, and ash content of vegetables and spices have also been regarded important for human health. Trace elements and heavy metals have certain risks [2], and thus it is important to determine the level of these compounds in widely consumed vegetables. In addition to vitamins, the presence of phytochemicals is also considered to be of crucial nutritional importance in the prevention of chronic diseases [3]. Hence knowledge of the chemical constituents of plants is desirable, not only for the discovery of therapeutic agents but also because such information may be of value in disclosing new sources of economical materials. In addition, the knowledge of the chemical constituents of plants would further be valuable in discovering the actual value of folkloric remedies [4].

Epidemiological and in vitro studies on plants, vegetables and spices strongly support the idea that several plant constituents are capable of exerting protective effects against oxidative stress in biological systems [5, 6]. Plants contain antioxidant compounds and these compounds protect cells against the damaging effects of reactive oxygen species (ROS) such as singlet oxygen, superoxide, peroxyl radicals, hydroxyl radicals and peroxynitrite which results in oxidative stress leading to cellular damage [7]. Considering the importance of phytoconstituents, in the present study an attempt has been made to analyse the proximate composition and micronutrient content in a green variety of capsicum (Capsicum annum L.), and also compare the free radical scavenging activity of the aqueous and hydro-ethanolic extract of green capsicum. In addition to its use as a spice, capsicum has long been used as traditional medicine for the treatment of a sore throat, cough, toothache, rheumatism, etc. [8]. Thus, evaluation of the nutritional profile and in vitro antioxidant potential of green capsicum might make it an important component of our daily diet.

\section{MATERIALS AND METHODS}

\section{Collection and authentication of plant material}

The green variety of Capsicum annum L., cultivated in Ghatakpukur, district 24 Parganas (South), West Bengal, and it was authenticated by Botanical Survey of India, Howrah, West Bengal (Specimen No: RMC/PHY/MD/01).

\section{Chemicals and reagents}

2, 2-diphenyl-1-picrylhydrazyl (DPPH), $\alpha$ - $\alpha^{\prime}$ dipyridyl and dinitro salicylic acid (DNS) were obtained from Sigma, Aldrich. Gallic acid, quercetin, rutin, butylated hydroxytoluene (BHT), 2-deoxy-2-ribose, potassium ferricyanide, trichloroacetic acid (TCA), ferric chloride $\left(\mathrm{FeCl}_{3}\right)$, ethylenediaminetetraacetic acid (EDTA), hydrogen peroxide $\left(\mathrm{H}_{2} \mathrm{O}_{2}\right)$, ascorbic acid, $\alpha$-tocopherol, 2-thiobarbituric acid (TBA), nitro blue tetrazolium (NBT), riboflavin were procured from HiMedia, Mumbai, India. Bromine, Folin ciocalteu, acetone, chloroform, 
copper sulphate $\left(\mathrm{CuSO}_{4}\right)$, dinitrophenylhydrazine (DNPH), hexane, metaphosphoric acid, xylene, sodium-potassium tartrate, potassium chloride $(\mathrm{KCl})$, sulphuric acid $\left(\mathrm{H}_{2} \mathrm{SO}_{4}\right)$, hydrochloric acid $(\mathrm{HCl})$, ethanol, methanol, aluminium chloride $\left(\mathrm{AlCl}_{3}\right)$, sodium carbonate $\left(\mathrm{Na}_{2} \mathrm{CO}_{3}\right)$, sodium nitrite $\left(\mathrm{NaNO}_{2}\right)$, sodium hydroxide $(\mathrm{NaOH})$, disodium hydrogen phosphate $\left(\mathrm{Na}_{2} \mathrm{HPO}_{4}\right)$, sodium dihydrogen phosphate $\left(\mathrm{NaH}_{2} \mathrm{PO}_{4}\right)$ were procured from Merck India Ltd, Mumbai. All chemicals were of analytical grade.

\section{Determination of nutrient and micronutrient content \\ Fresh tissue analysis}

$1 \mathrm{~g}$ of fresh tissue was smashed and homogenised with $10 \mathrm{ml}$ of $1(\mathrm{M})$ phosphate buffer $(\mathrm{pH}$ 7.4). The homogenate was centrifuged at $10,000 \times \mathrm{g}$ for $30 \mathrm{~min}$ at $4^{\circ} \mathrm{C}$ and the supernatant was used for further analysis.

\section{Proximate composition}

The parameters determined for proximate analyses include ash, moisture, crude protein, fat, fibre and carbohydrate. The proximate values were reported in percentage dry weight. Samples of the fresh tissue (5 grams, each) in triplicate were used for determination of moisture content by weighing in a crucible and drying in a hot air oven at $70{ }^{\circ} \mathrm{C}$, until a constant weight was obtained. Determination of ash content was done by ashing at $650{ }^{\circ} \mathrm{C}$ in muffle furnace for about 5 hours. Crude protein content was estimated using Lowry's method [9] and total and soluble carbohydrate was determined using dinitrosalicylic acid (DNS) method [10]. The crude fibre content of the samples was determined by acid-base digestion according to the method of Maynard [11]. Fat content was estimated according to the method of Itoch and Koneko [12]. The calorific value in, Kcalories per $100 \mathrm{~g}$ and the nutritive value in, calories per $100 \mathrm{~g}$ were estimated according to Eq. (1) [13] and Eq. (2) [14] respectively. Calorific value $=16.7 \mathrm{x} \%$ Carbohydrates $+16.7 \mathrm{x} \%$ Proteins $+37.7 \mathrm{x} \%$
Fats ................. (1)

Nutritive value $=4 \mathrm{x} \%$ Carbohydrates $+4 \mathrm{x} \%$ Proteins $+9 \mathrm{x} \%$ Fats (2)

\section{Mineral content}

Mineral content of green capsicum was determined by analysing aliquots of ash solution in $0.1(\mathrm{~N})$ hydrochloric acid $(\mathrm{HCl})$ after proper dilution, using inductively coupled plasma atomic emission spectrophotometer (ICP-AES) (M/s. Ametek Spectro Analytical Instruments $\mathrm{GmbH}$, Germany) along with smart analyser software. A multi-elemental standard solution of $1000 \mathrm{mg} / \mathrm{l}$ containing all analysed elements, supplied by National Institute of Standards and Technology (NIST) was used for calibration.

\section{Vitamin content}

\section{Determination of lycopene and $\beta$-carotene content}

$\beta$-Carotene and lycopene content were determined according to the method of Nagata and Yamashita (1992) [15]. Contents of $\beta$ carotene and lycopene were calculated according to Eq. (3) and Eq. (4). The results were expressed in terms of $\mathrm{mg} / 100 \mathrm{~g}$ dry weight of the tissue.

$$
\begin{gathered}
\text { Lycopene }(\mathrm{mg} / 100 \mathrm{ml})=-0.0458 \mathrm{~A}_{663}+0.204 \mathrm{~A}_{645}+0.372 \mathrm{~A}_{505}- \\
0.0806 \mathrm{~A}_{453} \ldots \ldots \ldots \ldots \ldots \ldots \ldots
\end{gathered}
$$

$\beta$-carotene $(\mathrm{mg} / 100 \mathrm{ml})=0.216 \mathrm{~A}_{663}-1.22 \mathrm{~A}_{645}-0.304 \mathrm{~A}_{505}+0.452 \mathrm{~A}_{453}$ (4)

\section{Determination of ascorbic acid content}

Ascorbic acid content was determined by the method of Riemschneider, 1976 [16] using 2, 4-dinitrophenyl hydrazine. Vitamin C concentration was expressed in terms of $\mathrm{g} / 100 \mathrm{~g}$ dry weight of the tissue from the standard curve with different concentrations of ascorbic acid $(10-60 \mu \mathrm{g} / \mathrm{ml})$.

\section{Determination of $\alpha$-tocopherol}

Vitamin E content was determined using the method of Baker et al. [17]. Vitamin E concentration was expressed in terms of g/100g dry weight of the tissue from the standard curve with different concentrations of $\alpha$-tocopherol $(20-100 \mu \mathrm{g} / \mathrm{ml})$.

\section{Processing of plant material}

The vegetable spice was cut into cubicles after washing with water. It was then shade dried and stored in airtight containers for further analysis.

\section{Preparation of aqueous and hydroethanolic extracts}

Shade dried cubicles of green capsicum were extracted using distilled water and $70 \%$ hydro-ethanol as solvents at $\left(60-80{ }^{\circ} \mathrm{C}\right)$ with the help of Soxhlet apparatus. $15 \mathrm{gm}$ of the sample was taken in the thimble of the Soxhlet and extracted in $200 \mathrm{ml}$ of the respective solvents, continuously for $72 \mathrm{~h}$. The mixture was then concentrated to dryness by using hot plate and rotary evaporator, respectively. The dried sample was then collected and stored in air tight plastic vials.

\section{Total phenol content (TPC)}

The total phenol of all extracts was measured spectrophotometrically using folin-ciocalteu reagent [18]. The dilute aqueous and ethanolic extracts $(0.5 \mathrm{ml}$ of $1 \mathrm{mg} / \mathrm{ml})$ and gallic acid (standard) was mixed with folin-ciocalteu reagent $(5 \mathrm{ml}, 1: 10$ diluted with distilled water) and aqueous sodium carbonate, and the absorbance was measured at $765 \mathrm{~nm}$.

\section{Total flavonoid content (TFC)}

Total flavonoid content was measured by aluminium chloride colorimetric assay [19]. Aqueous and ethanolic extracts $(1.0 \mathrm{ml}$ of 1 $\mathrm{mg} / \mathrm{ml}$ ) and different dilution of a standard solution of rutin (10$100 \mu \mathrm{g} / \mathrm{ml}$ ) were added to $10 \mathrm{ml}$ volumetric flask containing $4 \mathrm{ml}$ of water. To the above mixture, $0.3 \mathrm{ml}$ of $5 \% \mathrm{NaNO}_{2}, 0.3 \mathrm{ml}$ of $10 \%$ $\mathrm{AlCl}_{3}$ and $2 \mathrm{ml}$ of $\mathrm{NaOH}$ was added, and the total volume was made up to $10 \mathrm{ml}$ with distilled water. Then the solution was mixed well and the absorbance was measured against a freshly prepared reagent blank at $510 \mathrm{~nm}$.

\section{DPPH radical scavenging activity}

$0.1 \mathrm{mmol}$ solution of DPPH in ethanol $(22.2 \mathrm{mg}$ in $1000 \mathrm{ml})$ was freshly prepared. $1 \mathrm{ml}$ of different concentrations of aqueous (50$500 \mu \mathrm{g} / \mathrm{ml}$ ) and ethanolic extracts $(100-1000 \mu \mathrm{g} / \mathrm{ml})$ of green capsicum was added to $2 \mathrm{ml}$ of an ethanolic solution of DPPH. Ascorbic acid $(10-100 \mu \mathrm{g} / \mathrm{ml})$ was used as a standard. The absorbance was recorded at $517 \mathrm{~nm}[20,21]$. An IC 50 value was calculated as the concentration which brought about a $50 \%$ reduction in absorbance compared to blank.

\section{Hydroxyl radical scavenging activity}

Scavenging of hydroxyl free radical was measured by the method of Halliwell and Chirico [22], with slight modification. $200 \mu \mathrm{l}$ of 2 deoxy-2-ribose, $1 \mathrm{ml}$ of various concentrations of aqueous and ethanolic extracts $(200-1000 \mu \mathrm{g} / \mathrm{ml}), 400 \mu \mathrm{l}$ of $200 \mu \mathrm{M} \mathrm{FeCl}_{3}, 1.04$ mmol EDTA $(1: 1 \mathrm{~V} / \mathrm{V}), 200 \mu \mathrm{l}$ of $\mathrm{H}_{2} \mathrm{O}_{2}$ and $200 \mu \mathrm{l}$ ascorbic acid (1.0 $\mathrm{mmol}$ ) was mixed to form a reaction mixture. $1.5 \mathrm{ml}$ of $2.8 \%$ TCA and $1 \mathrm{ml}$ of $0.336 \%$ TBA was added and boiled for $20 \mathrm{~min}$ on boiling water bath. After cooling the absorbance was read at $532 \mathrm{~nm}$ against a blank. An $\mathrm{IC}_{50}$ value was calculated, and quercetin was used as a standard.

\section{Superoxide radical scavenging activity}

The reaction medium contained $2.5 \mathrm{ml}$ of phosphate buffer (pH 7.6), $100 \mu \mathrm{L}$ riboflavin $(20 \mu \mathrm{g}), 200 \mu \mathrm{L}$ EDTA (12 mmol), 100 $\mu \mathrm{L}$ NBT $(0.1$ $\mathrm{mg}$ ) and $1 \mathrm{ml}$ of various concentrations of aqueous $(100-500 \mu \mathrm{g} / \mathrm{ml})$ and ethanolic extracts $(200-1000 \mu \mathrm{g} / \mathrm{ml})$. The reaction was started by illuminating the reaction mixture for $5 \mathrm{~min}$. The absorbance was measured at $590 \mathrm{~nm}$. Blank was performed in the same way with 1 $\mathrm{ml}$ of methanol instead of test substance [23]. An IC 50 value was calculated using Ascorbic acid as standard.

The percentage inhibition activity for the above mentioned free radicals was calculated using Eq. (5): 


\section{Ferric reducing antioxidant power (FRAP) assay}

Various concentrations of aqueous and ethanolic extracts (100$1000 \mu \mathrm{g} / \mathrm{ml})$ and standard solutions of BHT $(100-500 \mu \mathrm{g} / \mathrm{ml}$ ) $2.5 \mathrm{ml}$ of phosphate buffer ( $\mathrm{pH} 6.6)$ and $2.5 \mathrm{ml}$ of $1 \%$ potassium ferricyanide were mixed separately and incubated at $50{ }^{\circ} \mathrm{C}$ for $30 \mathrm{~min}$. After incubation, $2.5 \mathrm{ml}$ of $10 \%$ TCA was added to each tube and centrifuged. About $2.5 \mathrm{ml}$ of the supernatant was diluted with $2.5 \mathrm{ml}$ water and shaken with $0.5 \mathrm{ml}$ of freshly prepared $0.1 \% \mathrm{FeCl}_{3}$. The absorbance was measured at $700 \mathrm{~nm}$ [24].

All tests were performed in triplicate, and the graph was plotted with the average of the three determinations.

\section{Statistical analysis}

All results were presented as mean \pm standard error (S. E.) of at least three individual experimental data, each in triplicate. Student's t-test was carried out to determine the level of significance. All statistical analyses were conducted using SPSS version 20.0

\section{RESULTS}

\section{Proximate analysis}

The mean values of the proximate composition are represented in fig. 1. The Calorific value is calculated to be $1822.89 \pm 3.18$ $\mathrm{Kcal} / 100 \mathrm{~g}$ and the Nutritive value is found to be $445.27 \pm 1.49$ $\mathrm{Cal} / 100 \mathrm{gm}$.

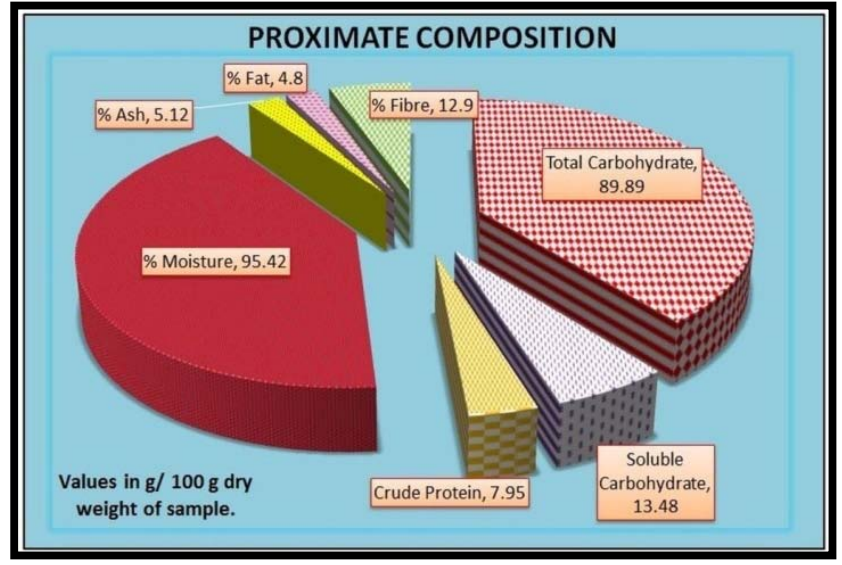

Fig. 1: Proximate Composition of Capsicum annum. Values are mean of three three sets of data $(n=3)$; each in triplicate

\section{Vitamin and mineral content}

Fig. 2 represents the amount of non-enzymatic antioxidants which include lycopene and $\beta$-carotene expressed in $\mathrm{mg} / 100 \mathrm{~g}$ dry weight of the sample, and ascorbic acid and $\alpha$-tocopherol expressed in $\mathrm{g} / 100 \mathrm{~g}$ dry weight of the sample, along with standard curves for ascorbic acid and $\alpha$-tocopherol.

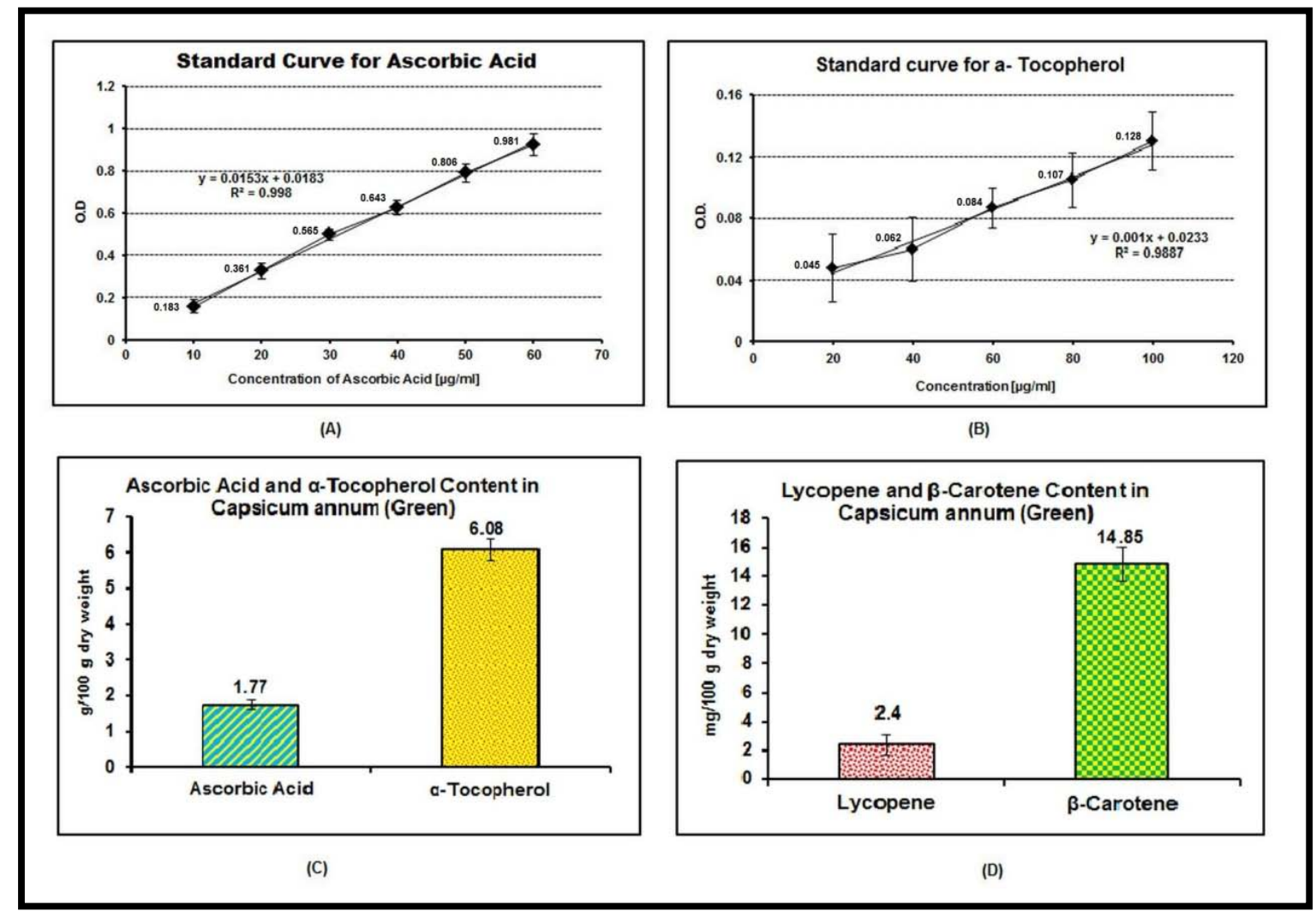

Fig. 2: Vitamin content of green Capsicum annum. (A) and (B): Standard curve for Ascorbic acid and $\alpha$-tocopherol respectively. (C): Ascorbic acid and $\alpha$-tocopherol content. (D): Lycopene and $\beta$-Carotene content. All data are expressed as MEAN $\pm S$. E., of triplicate set of values $(n=3)$

Table 1 represents the essential mineral content of green capsicum along with the dietary reference intakes (DRI) values based on older recommended dietary allowance (RDA) [25]. All values are expressed in $\mathrm{mg} / 100 \mathrm{~g}$ dry weight of the sample, except potassium which is expressed in $\mathrm{g} / 100 \mathrm{~g}$ dry weight of the sample. 
Table 1: Mineral content of green Capsicum annum,

\begin{tabular}{lll}
\hline Name of the mineral & Content [mg/100 gm dry weight] & DRI [mg] \\
\hline Sodium & $24.4 \pm 2.1$ & 2400 \\
Potassium & $2.236 \pm 0.27 \mathrm{a}$ & 4700 \\
Calcium & $19.56 \pm 0.18$ & 1300 \\
Copper & $1.11 \pm 0.03$ & 0.9 \\
Iron & $4.834 \pm 0.05$ & 18 \\
Magnesium & $92.612 \pm 4.57$ & 420 \\
Manganese & $0.88 \pm 0.02$ & 2.3 \\
Zinc & $1.632 \pm 0.19$ & 11 \\
Chromium & $0.016 \pm 0.06$ & 0.035 \\
Cobalt & $0.02 \pm 0.012$ & 0.008 \\
Boron & $0.316 \pm 0.09$ \\
\hline
\end{tabular}

All data are expressed as MEAN \pm SE, of triplicate set of values. ag/100 g dry weight of the sample. $(n=3)$

\section{Total phenol and flavonoid content}

The TPC of both the extracts is estimated as mg gallic acid equivalent/g dry weight of the sample. The TPC of the aqueous extract is found to be significantly higher $(\mathrm{p}<0.01)$ than the hydroethanolic extract.
The TFC of the extracts is expressed as mg of rutin equivalent/g dry weight of the sample. The TFC of the aqueous extract is found to be significantly higher $(\mathrm{p}<0.05)$ than the hydroethanolic extract. Fig. 3 below represents the TPC and TFC of green $C$. annum along with standard curves of gallic acid and rutin respectively.

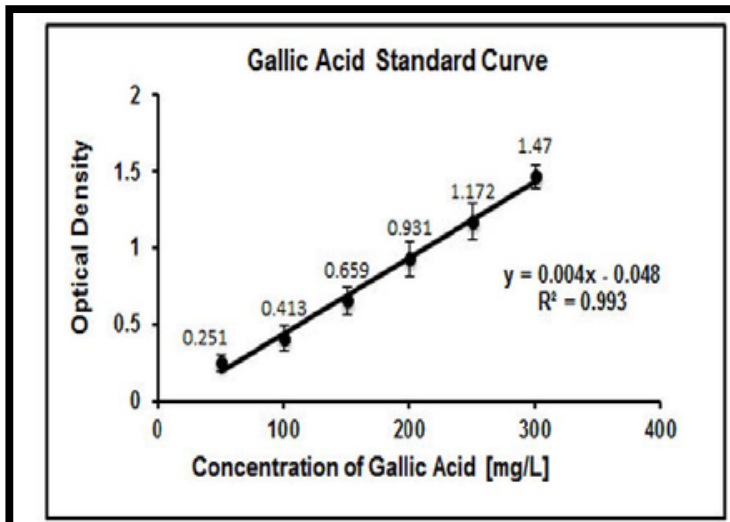

(A)

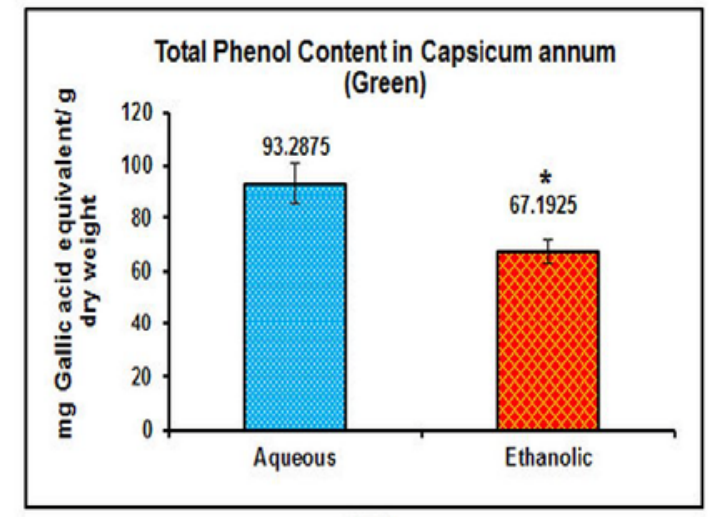

(C)

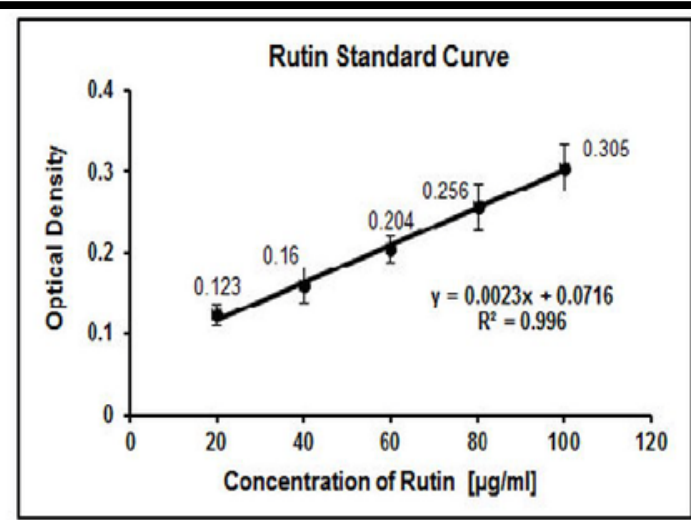

(B)

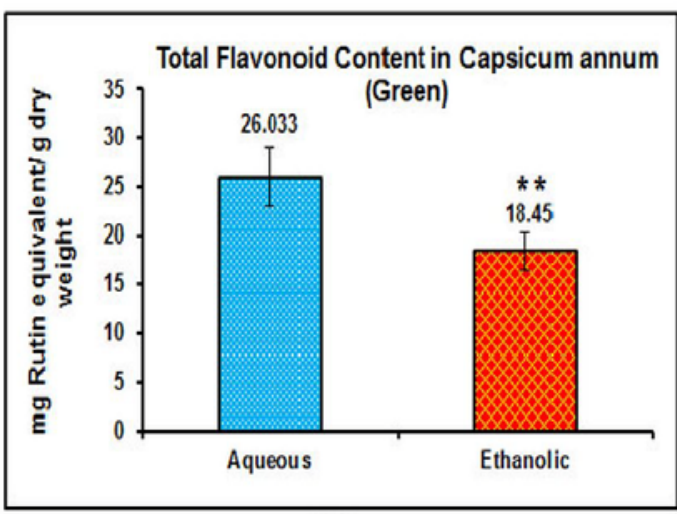

(D)

Fig. 3: Total phenol and flavonoid content of green Capsicum annum. (A) and (B): standard curve for Gallic acid and rutin respectively. (C) and (D): The total phenol and flavonoid content of green capsicum respectively; ${ }^{*}(\mathbf{p}<0.01),{ }^{* *}(\mathbf{p}<0.05)$. All data are expressed as mean $\pm S E$, of triplicate set of values $(n=3)$

\section{DPPH radical scavenging activity}

The colour of DPPH was quenched in a concentration-dependent manner by vitamin $\mathrm{C}$ and by the aqueous and hydroethanolic extracts of green $C$. annum as well. The $\%$ inhibition and IC $_{50}$ values of both the extracts along with its respective standard depicted in fig. 4 (A, B and E) below shows that aqueous extract of a green variety of $C$. annum possesses significantly higher $(p<0.01)$ DPPH radical scavenging activity than the hydro-ethanolic extract.

\section{Hydroxyl radical scavenging activity}

Both the aqueous and hydroethanolic extracts of green $C$. annum have the potential to scavenge hydroxyl radical produced in vitro by fenton reaction. A significantly lower $(p<0.01) \quad I_{50}$ value of the 
aqueous extract thus indicates that the aqueous extract is more potential than the hydro-ethanolic extract. The \% inhibition of the aqueous extract is also significantly higher $(\mathrm{p}<0.01)$ than the hydroethanolic extract. (fig. 4D and 4E)

\section{Superoxide radical scavenging activity}

Fig. 4C depicts that the superoxide radical scavenging activity of the aqueous extract is significantly higher than the hydro-ethanolic extract. As relevant from fig. $4 \mathrm{E}$ a significantly lower $\mathrm{IC}_{50}$ value $(\mathrm{p}<0.01)$ of the aqueous extract, makes it more potential in quenching superoxide radical compared to the hydro-ethanolic extract.

\section{Ferric reducing antioxidant power (FRAP) assay}

FRAP assay is based on its ability of the extracts to reduce ferric $\left(\mathrm{Fe}^{3+}\right)$ to ferrous $\left(\mathrm{Fe}^{2+}\right)$ state. Fig. $4(\mathrm{~F})$ shows an increase in reducing power of both the extracts in a dose-dependent manner. However, the aqueous extract is found to be more potent compared to the hydro-ethanolic extract.

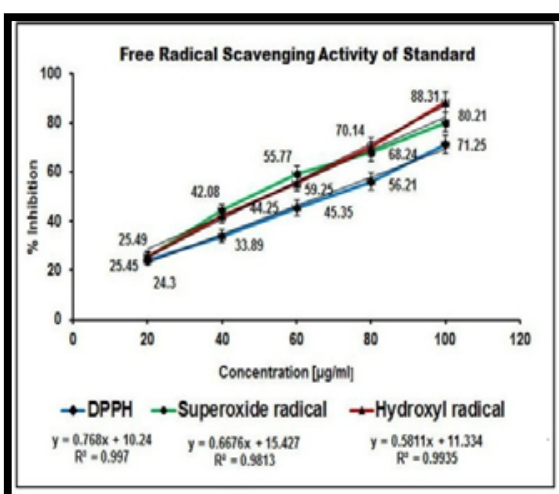

(A)

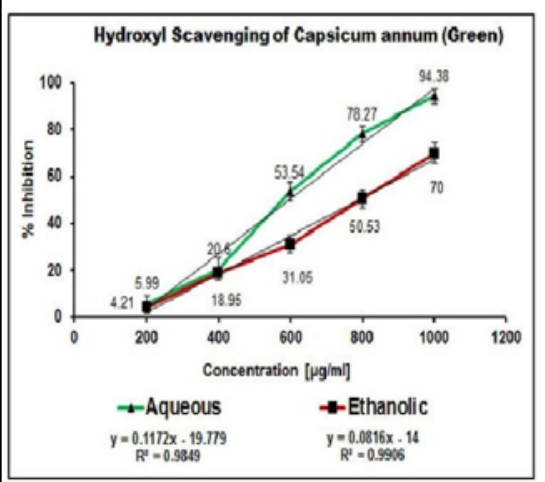

(D)

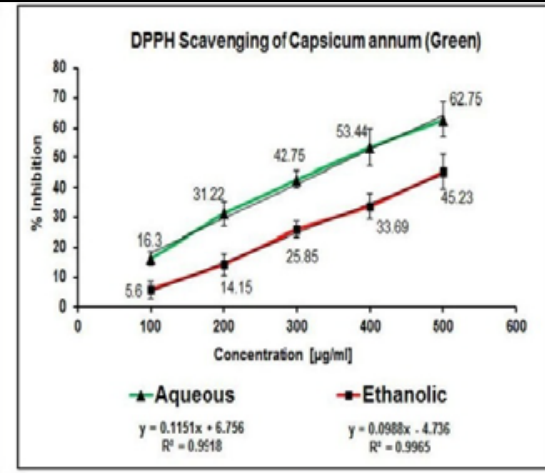

(B)

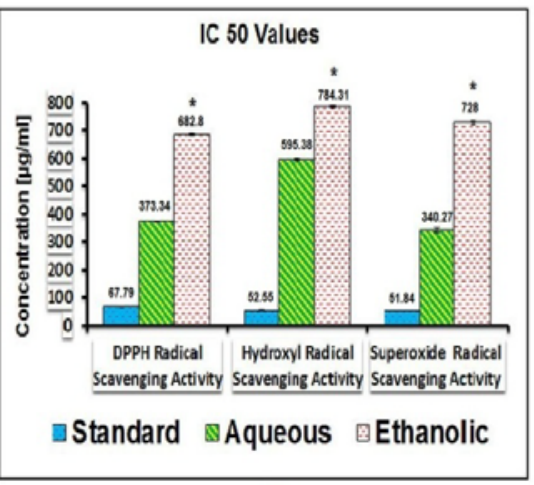

(E)

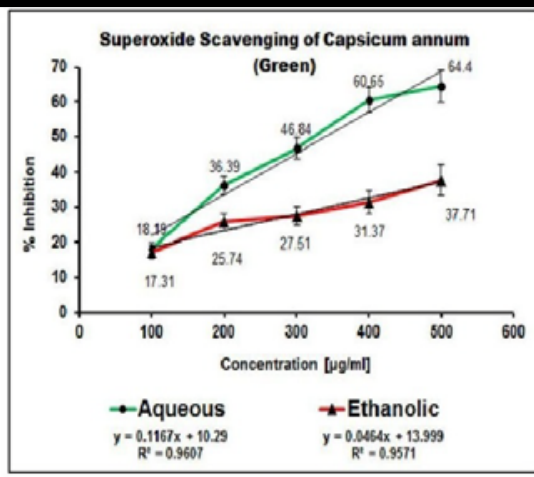

(C)

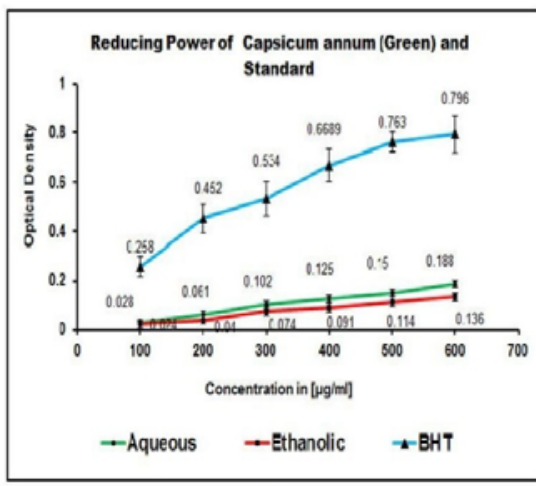

(F)

Fig. 4: Free radical scavenging activity of standard and sample in a dose-dependent manner (A): the Free radical scavenging activity of the standards for DPPH, Hydroxyl and Superoxide radicals, and that of the extracts (B), (C), (D). (E): IC 50 values of extracts and standards. (F): Ferric reducing the power of the extracts and standard. All data are expressed as $M E A N \pm S$. E., of triplicate set of values (n=3). $(p<0.01)$

\section{DISCUSSION}

The presence of important nutrients like carbohydrate, protein and fat makes the green variety of $C$. annum a nutritionally valuable and healthy ingredient to promote health. Compared to some conventional sources of carbohydrate, such as cereals, $C$. annum can be considered as a potential source of carbohydrate. The percentage ash represents the inorganic content of the vegetable. Moreover, low fat and high dietary fibre content of green capsicum makes it a promising food recommended as part of the weight-reducing diet for obese people. High food fibre aids absorption of trace elements in the gut [26] and reduces absorption of cholesterol [27]. Thus, fibre reduces the risk of coronary heart disease, hypertension, constipation, diabetes, colon and breast cancer $[28,29]$.

In living systems, free radicals are constantly generated, and they can cause extensive damage to tissues and biomolecules leading to various disease conditions, especially degenerative diseases, and extensive lysis. Many synthetic drugs protect against oxidative damage, but they have adverse side effects. An alternative solution to the problem is to consume natural antioxidants from food supplements and traditional medicines [30]. Antioxidant vitamins like vitamin $\mathrm{C}$ and vitamin $\mathrm{E}$ act synergistically against oxidative stress-related diseases. Vitamin $\mathrm{E}$ functions as a chain-breaking antioxidant which prevents the propagation of free radical reactions whereas; vitamin $\mathrm{C}$ is a part of the normal immune mechanism in humans. Lycopene and $\beta$-carotene add on to the antioxidant potential of the vegetable.

Moreover, green $C$. annum is found to be abundant in potassium content. The high amount of potassium is reported to increase iron utilisation [31] and is also beneficial for people suffering from hypertension [32]. In comparison to the potassium content, the sodium content of green capsicum is low. Thus, a lower sodium/potassium ratio makes green capsicum a recommended nutrient to reduce the risk of elevated blood pressure. Calcium is essential not only for children but also for pregnant, lactating and menopausal women. The presence of calcium in green capsicum might be useful in preventing diseases such as osteoporosis. Besides, minerals are also required for normal growth, skeletal development and contraction of muscles (such as calcium), cellular activity and oxygen transport (copper and iron), chemical reaction in the body and intestinal absorption (magnesium and zinc), fluid balance and nerve transmission (sodium and potassium), as well as for the regulation of acid-base balance (phosphorus). Iron is useful in the prevention of anaemia and other related diseases [33]. Manganese acts as a cofactor in some enzymes and also plays a role in energy production and in supporting the immune system. Zinc is useful for 
protein and nucleotide synthesis, normal body development and recovery from illness [34].

Cobalt plays a role in the metabolism of vitamin B-12 and increases its absorption; it also functions as an activating ion in some enzymes [35]. Chromium content of the vegetable is also within the safety limit. Boron assists and improves retention of minerals like calcium, magnesium, and phosphorus; necessary for brain function, memory and alertness, as well as for the activation of vitamin D [36]. The presence of the above-mentioned macro and micro nutrients in green $C$. annum might be essential in preventing diseases related to malnutrition.

Heavy metal content (arsenic, lead, cadmium and mercury) of the vegetable is also analysed, and interestingly no trace of heavy metal was found. The absence of heavy metals like mercury, lead, cadmium and arsenic in the collected specimens of green capsicum reveals the quality of soil and water used for irrigation. This is in accordance with a recently published data which states the absence of heavy metals in fruits and vegetables collected from Ghatakpukur region of 24 Parganas (South), West Bengal [37].

It is said that secondary metabolites such as phenols and flavonoids contribute to the antioxidant potential of the plant material [38]. The aqueous and hydroethanolic extracts of green capsicum are considered as good sources of antioxidants as shown by their total phenolic and flavonoid contents.

Previously it has been reported that the antioxidant activity of green capsicum is more than the red and yellow variety [39]. Interestingly, in the present study, it is observed that using water as a solvent for extraction was better compared to the hydro-ethanolic solvent. The free radical scavenging activity of both the extracts also confirms that the aqueous extract is more potent in quenching free radicals than the hydro-ethanolic extract. Reducing power, a significant indicator of the antioxidant property also suggests that the aqueous extract has a greater ferric to ferrous reducing power.

Although it has been stated that water extraction of plant organs leaves a large amount of residual polyphenols that can be extracted only by an appropriate combination of solvents [40]; literature also suggests that for some herbs and spices like sage, water as a solvent for extraction is more effective [41]. Thus, it can be concluded that polyphenols are either polar or non-polar. Moreover, the temperature for polyphenol extraction, as well as the incubation time, also contributes to the efficacy of the antioxidant activity [4244]. However, contradicting the above results, few studies also suggested that the total amount of phenolic acids and flavonoids decreased after heat treatment $[45,46]$. This indicated that some phenolic acids probably are heat labile, whereas others are converted from insoluble phenolic compounds to soluble phenolics after heat treatment. Thus, in the present study, the higher antioxidant potential of the aqueous extract might be attributed to the higher boiling point of water than $70 \%$ hydro-ethanolic solvent.

\section{CONCLUSION}

From the present study, it can be concluded that green Capsicum annum $L$. contains an appreciable amount of carbohydrate, protein, vitamins and minerals, which if properly utilised could assist in combating the problem of malnutrition. Moreover, both the extracts of Capsicum annum $L$. also possess high antioxidant potential and can thus serve as a good source of natural antioxidant; the aqueous extract being more potent than the hydro-ethanolic extract. Thus Capsicum annum $L$. can become an important nutraceutical spice and can be used in the formulation of herbal drugs in the years to come. Further research on isolation of bioactive components along with its pharmacological activities is necessary for a novel drug development.

\section{ACKNOWLEDGEMENT}

The authors acknowledge the authority of Rammohan College for providing the facilities to conduct the experiments. Dr. Pranabes Nath of Department of Physiology, Rammohan College is also highly acknowledged for his kind co-operation and guidance. Special thanks are also due to Dr. Uttpal RoyChoudhury of National Test
House, Kolkata, particularly for studying the mineral content of the extract.

\section{CONFLICT OF INTERESTS}

Declared none

\section{REFERENCES}

1. Mahapatra AK, Mishra S, Basak UC, Panda PC. Nutrient analysis of some selected edible fruits of deciduous forests of India: an explorative study towards nonconventional bio-nutrient. Adv J Food Sci Technol 2012;4:15-21.

2. Schumacher M, Bosque MA, Domingo JL, Corbella J. Dietary intake of lead and cadmium from food in Tarragona Province, Spain. Bull Environ Contam Toxicol 1991;46:320-8.

3. Aruoma OL. Methodological consideration for characterising potential antioxidants actions of bioactive components in plant foods. Mutat Res Fundam Mol Mech Mutagen 2003;523-524:9-20.

4. Singh S. Phytochemical analysis of different parts Prosopis juliflora. Int J Curr Pharm Res 2012;4:59-61.

5. Ardanaz N, Pagano PJ. Hydrogen peroxide as a paracrine vascular mediator: regulation and signalling leading to dysfunction. Exp Biol Med 2006;231:237-51.

6. Ness AR, Powles JW. Fruit and vegetables and cardiovascular disease: a review. Int J Epidemiol 1997;26:1-13.

7. Nisha S, Vishnupriya M, Sasikumar JM, Hephzibah PC, Gopalakrishnan VK. Antioxidant activity of ethanolic extract of Maranta arundinacea. $L$ tuberous rhizomes. Asian J Pharm Clin Res 2012;5:85-8.

8. Singletary K. Red pepper: an overview of potential health benefits. Nutr Today 2011;46:33-47.

9. Lowry $\mathrm{OH}$, Rosebrough NJ, Farr AL, Randal RJ. Protein measurement with folin-phenol reagent. J Biol Chem 1951;193:265-75.

10. Miller GL. Use of dinitro salicylic acid reagent for determination of reducing sugar. Anal Chem 1959;31:426-8.

11. Joslyn MA. Methods in Food Analysis. $2^{\text {nd }}$ edition. New York: Academic Press; 1970.

12. Itoch L, Kaneko H. Yeast lipids in species variation. I. A simple method for stimulating cellular lipids. J Pharm Soc Japan 1974;23:350-4.

13. Aberoumand A. Screening of less known two food plants for comparison of nutrient contents: Iranian and Indian vegetables. Funct Foods Health Dis 2011;10:416-23.

14. Indrayan AK, Sharma S, Durgapal D, Kumar N, Kumar M. Determination of nutritive value and analysis of mineral elements for some medicinally valued plants from Uttaranchal. Curr Sci 2005;89:1252-5.

15. Nagata M, Yamashita I. Simple method for simultaneous determination of chlorophyll and carotenoids in tomato fruit. J Japan Soc Food Sci Technol 1992;39:925-8.

16. Riemschneider R, Abedin MZ, Mocellin RP. Qualities and stabilisierungprufung hitzekonservierter Nahrungsmittelunter verwendung von Vit C alskrikriterium-Mittel Alimentum 1976;15:171.

17. Baker H, Frank O. Determination of serum tocopherol. In: Gowenlock AH, McMurray JR, Mc Lauchlan DM. editors. Varley's Practical Clinical Biochemistry. $6^{\text {th }}$ ed. London: Heinemann Medical Books; 1988. p. 902.

18. McDonald S, Prenzler PD, Autolovich M, Robards K. Phenolic content and antioxidant activity of olive extracts. Food Chem 2001;73:73-84.

19. Kumar S, Dinesh K, Manjusha, Sarodha K, Nidhan S, Bhoodev V. Antioxidant and free radical scavenging potential of Citrullus colocynthis (L.) Schrad. methanolic fruit extract. Acta Pharm 2008;58:215-20.

20. Sreejayan N, Rao MN. The free radical scavenging activity of curcuminoids. Drug Res 1996;46:169-71.

21. Mohammad TA. Determination of polyphenolic content and free radical scavenging activity of Flemingia strobilifera. Adv Pharmacol Toxicol 2009;10:89-95.

22. Halliwell B, Chirico S. Lipid peroxidation: Its mechanism, measurement and significance. Am J Clin Nutr 1993;57 Suppl $5: 715 s-25 s$. 
23. Halliwell B, Gutteridge JMC, Aruoma OI. The deoxyribose method: a simple 'test tube' assay for determination of rate constants for reactions of hydroxyl radicals. Anal Biochem 1987;165 Suppl 1:215-9.

24. Beuchamp C, Fridovich I. Superoxide dismutase: improved assays and assay applicable to acrylamide gels. Anal Biochem 1971;44:276-87.

25. Oyaizu M. Studies on products of browning reactions: antioxidative activities of products of browning reaction prepared from glucosamine. Japan J Nutr 1986;44:307-15.

26. Kelsay JL. Effects of diet fibre on bowel function and trace mineral balances of human subjects. Cereal Chem 1981;58:2-5.

27. LeVeille GA, Sauberlich HE. Mechanism of the cholesteroldepressing effect of pectin in the cholesterol-fed rat. J Nutr 1966;88:209-14.

28. Hanif R, Iqbal Z, Iqbal M, Hanif S, Rasheed M. Use of vegetables as nutritional food: role in human health. J Agric Biol Sci 2006;1:18-22.

29. Jimoh FO, Adedapo AA, Aliero AA, Koduru S, Afolayan AJ. Evaluation of the polyphenolic, nutritive and biological activities of the acetone, methanol and water extracts of Amaranthus asper. Open Complementary Med J 2010;2:7-14.

30. Indhumati $\mathrm{T}$, Sruthi G, Mohandas S. Comparative phytochemical analysis and free radical scavenging activity in different extracts of peel and pulp of Actinidia Chinensis. Asian J Pharm Clin Res 2011:4 Suppl 2:96-9.

31. Council for Responsible Nutrition. National Academy Press: Washington DC; 2001.

32. Adeyeye EI. Determination of the chemical composition of the nutritionally valuable parts of male and female common West African fresh water crab (Sudananoutes africanus). Int J Food Sci Nutr 2002;53:189-96.

33. Arinanthan V, Mohan VR, De Britto AJ. The chemical composition of certain tribal pulses in South India. Int J Food Sci Nutr 2003;54:209-17.

34. Oluyemi EA, Akilua AA, Adenuya AA, Adebayo MB. Mineral contents of some commonly consumed Nigerian foods. Sci Focus 2006;11:153-7.

35. Dangoggo SM, Muhammad A, Tsafe AI, Aliero AA, Itodo AU. Proximate, mineral and anti-nutrient composition of Gardenia Aqualla seeds. Arch Appl Sci Res 2011;3:485-92.

36. Cabrera C, Lorenzo ML, DeMena C, Lopez MC. Chromium, copper, iron, manganese, selenium and zinc levels in dairy products: In vitro study of absorbable fractions. Int J Food Sci Nutr 1996;47:331-8.

37. Banerjee D, Bairagi H, Mukhopadhyay S, Pal A, Bera D, Ray L. Heavy metal contamination in fruits and vegetables in two districts of West Bengal, India. Electron J Environ Agric Food Chem 2010;9:1423-32.

38. Kahkonen MP, Hopia AI, Vuorela HJ, Rauha JP, Pihlaja K, Kujula TS, et al. Antioxidant activity of plant extracts containing phenolic compounds. J Agric Food Chem 1999;47:3954-62.

39. Khabade VK, Lakshmeesh NB, Roy S. Comparative study on antioxidant and anti-inflammatory properties of three coloured varieties of Capsicum annuum. Int J Fundamental Appl Sci 2012;1:51-4.

40. Koffi E, Sea T, Dodehe Y, Soro S. Effect of solvent type on the extraction of polyphenols from twenty-three Ivorian plants. J Anim Plant Sci 2010;5:550-8.

41. Ollanketo M, Peltoketo A, Hartonen K, Hiltunen R, Riekkola ML. Extraction of sage (Salvia officinalis L.) by pressurised hot and conventional methods: antioxidant activity of the extracts. Eur Food Res Technol 2002;215:158-63.

42. Tomaino A, Cimino F, Zimbalatti V, Venuti V, Sulfaro V, Pasquale DA, et al. Influence of heating on antioxidant activity and the chemical composition of some spice essential oils. Food Chem 2005;89:549-54.

43. Kim SY, Jeong SM, Park WP, Nam KC, Ahn AU, Lee SC. Effect of heating conditions of grape seeds on the antioxidant activity of grape seed extracts. Food Chem 2006;97:472-9.

44. Shotorbani NY, Jamei R, Heidar R. Antioxidant activities of two sweet pepper Capsicum annuum L. varieties phenolic extracts and the effects of thermal treatment. Avicenna J Phytomed 2013;3:25-34.

45. Xu G, Ye X, Chen J, Liu D. Effect of heat treatment on the phenolic compound and antioxidant capacity of citrus peel extract. J Agric Food Chem 2007;55:330-5.

46. Aoyama S, Yamamoto Y. Antioxidant activity and flavonoid content of Welsh onion (Allium fistulosum) and the effect of thermal treatment. Food Sci Technol Res 2007;13:67-72.

\section{How to cite this article}

- Moumita Das, Subhashree Basu, Anurupa Sen, Gouriprosad Datta. Nutritional profile, mineral content and in the vitro antioxidant potency of Capsicum annum L. cultivated in 24 parganas [South], West Bengal, India. Int J Pharm Pharm Sci 2017;9(1):182-188. 